\title{
Effect of Pulsed Current on Temperature Distribution and Characteristics of GTA Welded Magnesium Alloy
}

\author{
N. Karunakaran \\ Department of Mechanical Engineering, Annamalai University, Annamalai Nagar - 608002, India.
}

\begin{abstract}
This paper compares temperature distribution and weld bead profiles of constant current and pulsed current gas tungsten arc welded AZ31B magnesium alloy joints. The effect of pulsed current welding on tensile properties, hardness profiles, microstructural features and residual stress distribution are reported. The use of pulsed current technique has been found to improve the tensile properties of the welds compared to those of continuous current welds due to grain refinement occurring in the fusion zone.
\end{abstract}

Keywords: magnesium alloy, gas tungsten arc welding, pulsed current, temperature distribution, bead profiles, tensile properties.

\section{INTRODUCTION}

Reduction of weight is a prime concern for many industries involved in transportation, especially the automobile industry,because of fuel saving, reduction of emission and recyclability. Hence, the focus on lightweight materials likes magnesium is gaining importance. Weldability of magnesium alloys has recently been investigated with the Gas Tungsten Arc Welding (GTAW) process [1,2]. Of all commercial magnesium alloys, those with aluminium as the primary alloying element are most weldable using this process.

In conventional welding, the fusion zone exhibits typically coarse columnar grains because of the faster cooling rate during weld metal solidification. This often results in inferior weld mechanical properties and poor resistance to hot cracking. It is thus highly desirable to control solidification structure in welds and such control is often very difficult because of higher temperatures and higher thermal gradients in welds in relation to castings and the epitaxial nature of the growth process. Nevertheless, several methods for refining weld fusion zones have been tried with some success in the past: inoculation with heterogeneous nucleants, micro cooler additions, and surface nucleation induced by gas impingement and introduction of physical disturbance through techniques such as torch vibration [3]. In the GTAW process, two relatively new techniques namely, magnetic arc oscillation and current pulsing, have gained wide popularity because of their striking promise and the relative ease with which these techniques can be applied to actual industrial situations with only minor modifications of the existing welding equipment [4].

Pulsed current GTAW, developed in 1950s, is a variation of GTA welding which involves cycling of the welding current from a high level to a low level at a selected regular frequency. The high level of the peak current is generally selected to give adequate penetration and bead contour, while the low level of the background current is set at a level sufficient to maintain a stable arc. This permits arc energy to be used efficiently to fuse a spot of controlled dimensions in a short time producing the weld as a series of overlapping nuggets and limits the wastage of heat by conduction into the adjacent parent material as in normal constant current welding. In contrast to constant current welding, the fact that heat energy required to melt the base material is supplied only during peak current pulses for brief intervals of time allows the heat to dissipate into the base material leading to a narrower heat affected zone (HAZ). The technique has secured a niche for itself in specific applications such as in welding of root passes of tubes, and in welding thin sheets, where precise control over penetration and heat input are required to avoid burn through [5].

Extensive research has been performed in pulsed GTAW process and the advantages reported include improved bead contour, greater tolerance to heat sink variations, lower heat input requirements, reduced residual stresses and distortion [6]. Metallurgical advantages of pulsed current welding reported frequently in the literature include refinement of fusion zone grain size and substructure, reduced width of HAZ, control of segregation, etc [7]. All these factors should help in improving mechanical properties. Current pulsing has been used $[8,9]$ to obtain grain refinement in the weld fusion zone and improvement in weld mechanical properties of aluminium alloys, titanium alloys and stainless steel. However, there is no literature available on the effect of pulsed current on temperature distribution and bead profiles and their subsequent influence on tensile properties, hardness profiles and microstructure characteristics. Hence, the present investigation was carried out on gas tungsten arc welded AZ31B magnesium alloy joints. 


\section{EXPERIMENTAL PROCEDURE}

The base material was rolled sheets of $2 \mathrm{~mm}$ thick. The chemical composition and mechanical properties are presented in TABLE 1 and 2 . The sheets were cut to the required size $(100 \times 100 \mathrm{~mm})$ by power hacksaw cutting and grinding. Square butt joint configuration was used to fabricate welded joints. Single pass, autogenous welding procedure (without filler metal addition) was applied to fabricate the joints. High purity argon gas (99.99\%) was used as shielding gas with a flow rate of $9 \mathrm{lpm} .2 \%$ Thoriated Tungsten electrode of $3.2 \mathrm{~mm}$ diameter was used with DC straight polarity (electrode - ve and weld plate $+\mathrm{ve}$ ) for welding. The arc length was maintained at $2 \mathrm{~mm}$.

TABLE 1 CHEMICAL COMPOSITION (WT\%) OF BASE METAL
\begin{tabular}{llll}
$\mathrm{Al}$ & $\mathrm{Mn}$ & $\mathrm{Zn}$ & $\mathrm{Mg}$ \\
\hline 3.0 & 0.2 & 1.0 & Balance \\
\hline
\end{tabular}

TABLE 2 MEChANICAL PROPERTIES OF BASE METAL

\begin{tabular}{cccc}
\hline $\begin{array}{c}\text { Yield Strength } \\
(\mathrm{MPa})\end{array}$ & $\begin{array}{c}\text { Tensile Strength } \\
(\mathrm{MPa})\end{array}$ & $\begin{array}{c}\text { Elongation in } 50 \mathrm{~mm} \text { gauge } \\
\text { length }(\%)\end{array}$ & $\begin{array}{c}\text { Micro Hardness at 0.05 } \\
\text { Kg load (Hv) }\end{array}$ \\
\hline 176 & 215 & 14.7 & 69 \\
\hline
\end{tabular}

The experimental setup is shown in Fig 1. The LINCOLN ELECTRIC GTAW machine controlled the welding parameters, model: "Precision TIG 375". To measure the temperature during welding the K Type Chromel Alumel thermocouple was used $[10,11,12]$. The hot end diameter of the thermocouple was $1.5 \mathrm{~mm}$, the cold end was fixed to a thermocouple bank and data acquired using digital interface LABVIEW having the flexibility to measure the parameter of concern at very short interval. When used on DC straight polarity LABVIEW acquired data both for heating and cooling, but in AC configuration data were acquired only after the welding time, hence providing temperature history for the cooling. This being the limitation the DC straight polarity was used for the investigation. Fig 2 shows the positions on the plate where the thermocouples were glued to a depth of $1 \mathrm{~mm}$ in the holes drilled at the bottom of the plate [13]. The data on the temperature were acquired every second during welding from these 3 locations as well as the room temperature.

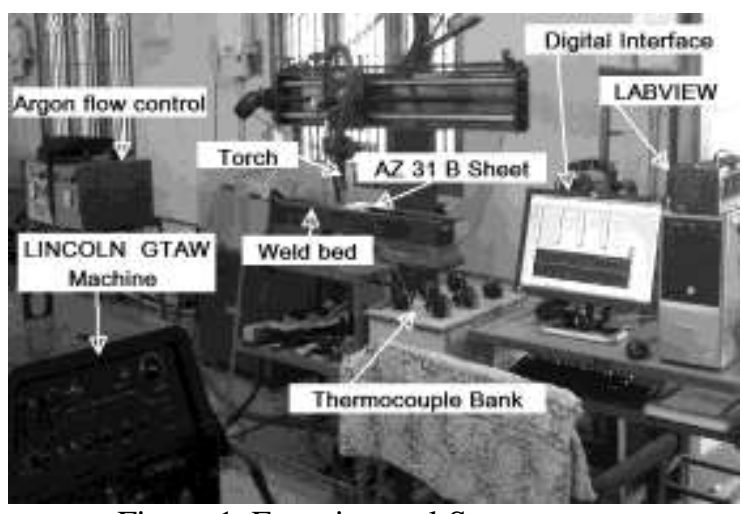

Figure 1. Experimental Setup

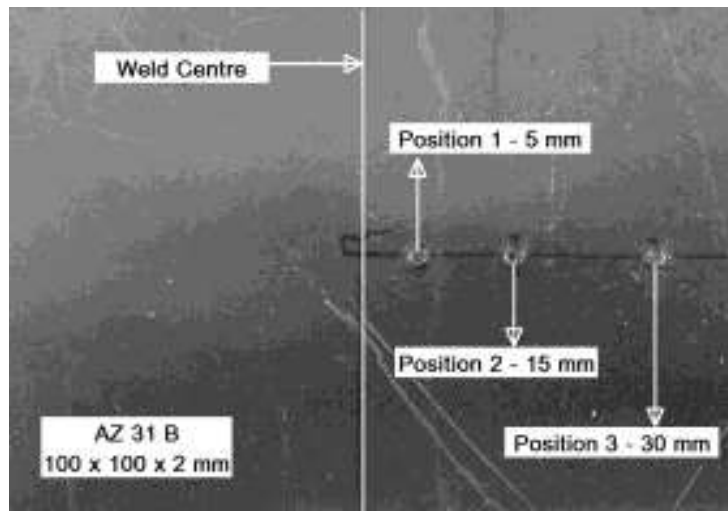

Figure 2. Thermocouple positions

Before welding the plates were cleaned and thermocouples were incorporated at appropriate positions. Welding was done by both the constant current (CC) and the pulsed current (PC) process. A number of trials were run on to fix the upper and lower heat input levels. For the CC, process higher than $120 \mathrm{amps}$ resulted in burning of base metal and in PC process, the burning happened above $160 \mathrm{amps}$.

$\mathrm{Lu}$, M.and Kou, S., [10] showed for the GTAW process, that the molten surface is turbulent if the welding current is more than $225 \mathrm{~A}$. The frequency was fixed at $6 \mathrm{hz}$ [14]. The welding parameters used in the present investigation are shown in TABLE 3 and 4.

TABLE 3 CONSTANT CURRENT WELDING PARAMETERS

\begin{tabular}{cccccc}
\hline $\begin{array}{c}\text { Experiment } \\
\text { No }\end{array}$ & $\begin{array}{c}\text { Current } \\
\text { (amps) }\end{array}$ & $\begin{array}{c}\text { Voltage } \\
\text { (volts) }\end{array}$ & $\begin{array}{c}\text { Welding speed } \\
(\mathrm{mm} / \mathrm{sec})\end{array}$ & Efficiency (\%) & $\begin{array}{c}\text { Heat Input } \\
(\text { Joules/mm) }\end{array}$ \\
\hline 1 & 80 & 11.3 & 4.167 & 70 & 152 \\
\hline 2 & 90 & 12.5 & 4.167 & 70 & 189 \\
\hline 3 & 100 & 12.5 & 4.167 & 70 & 210 \\
\hline 4 & 110 & 12.7 & 4.167 & 70 & 235 \\
\hline 5 & 120 & 13 & 4.167 & 70 & 262 \\
\hline
\end{tabular}


Effect of pulsed current on temperature distribution, and characteristics of GTA welded magnesium

\begin{tabular}{ccccccccc}
\multicolumn{7}{c}{ TABLE 4 PULSED CURRENT WELDING PARAMETERS } \\
\hline $\begin{array}{c}\text { Exp } \\
\text { No }\end{array}$ & $\begin{array}{c}\text { Peak } \\
\text { Current } \\
(\mathrm{amps})\end{array}$ & $\begin{array}{c}\text { Base } \\
\text { Current } \\
(\mathrm{amps})\end{array}$ & $\begin{array}{c}\text { Voltage } \\
(\text { volts })\end{array}$ & $\begin{array}{c}\text { Pulse on } \\
\text { time }(\%)\end{array}$ & $\begin{array}{c}\text { Freque } \\
\text { ncy } \\
(\mathrm{hz})\end{array}$ & $\begin{array}{c}\text { Welding } \\
\text { speed } \\
(\mathrm{mm} / \mathrm{sec})\end{array}$ & $\begin{array}{c}\text { Efficien } \\
\text { cy }(\%)\end{array}$ & $\begin{array}{c}\text { Heat Input } \\
(\text { Joules/mm }\end{array}$ \\
\hline 1 & 120 & 60 & 12.1 & 50 & 6 & 4.167 & 70 & 193 \\
\hline 2 & 130 & 65 & 11.5 & 50 & 6 & 4.167 & 70 & 199 \\
\hline 3 & 140 & 70 & 12 & 50 & 6 & 4.167 & 70 & 223 \\
\hline 4 & 150 & 75 & 12.5 & 50 & 6 & 4.167 & 70 & 249 \\
\hline 5 & 160 & 80 & 12.4 & 50 & 6 & 4.167 & 70 & 263 \\
\hline
\end{tabular}

For the calculation of the heat Input $(\mathrm{Q})$ the relationship used for $\mathrm{CC}$ process was $\mathrm{Q}=\{(\mathrm{VxI}) / \mathrm{n}\} \eta$ where $\mathrm{V}$ is the voltage, $\mathrm{I}$ is the current, $\mathrm{n}$ is the welding speed and $\eta$ is the efficiency of utilization of the heat generated $[15,16]$. The calculation of heat input for the PC process was done by first computing the Mean Current using the relationship $\operatorname{Im}=\left\{\left(\mathrm{I}_{\mathrm{p}} \mathrm{x} \mathrm{t}_{\mathrm{p}}\right)+\left(\mathrm{I}_{\mathrm{b}} \mathrm{xt} \mathrm{t}_{\mathrm{b}}\right)\right\} / \mathrm{t}_{\mathrm{T}}$. Where Im is the mean current, $\mathrm{I}_{\mathrm{p}}$ is the peak current, $\mathrm{I}_{\mathrm{b}}$ is the base current, $t_{p}$ is the time on peak pulse, $t_{b}$ is the time on base current, $t_{T}$ is the total time $[16,17,18]$. From this the RMS value of current or the effective current was computed and the heat input values tabulated in Table 4. Both the processes were performed at the same speed and the efficiency of utilization of the heat generated was taken as $70 \%[15,16]$.

\subsection{Characterization of welded specimen 2.1.1 Tensile properties}

The transverse tensile properties of the welded joints were evaluated using the Universal Testing Machine (UTM). The specimens were prepared as per the ASTM E8-04 standards and three specimen from the mid portion of each joint were tested.

\subsubsection{Hardness}

A microhardness testing machine (SHIMADZU HMV-2 Version 2.02) was used to measure the hardness at the weld bead, $5 \mathrm{~mm}$ and $15 \mathrm{~mm}$ from the weld centre. A load of $50 \mathrm{~g}$ was applied for 15 seconds, to obtain the Vickers hardness HV/0.05.

\subsubsection{Microstructure}

The welded specimen was prepared using the standard metallographic procedure, the polished surfaces were etched with aqua-reagent to get the clear microscopic view of the weldment. The optical microscope (MEIJI Japan Model MIL7100) was used with the software Metalvision MVLx 1.0.

\subsubsection{Residual Stress}

The residual stress distribution in the transverse direction was measured by the $\mathrm{X}$ ray diffraction method. The equipment used to measure the stress was X3000 (Ver 1.22.9) the software Stress tech was used to compile the value of stress from the measured value of "d " in the Bragg's equation. The residual stress was measured for one specimen in each of the two process and at the weld bead, $5 \mathrm{~mm}$ and $10 \mathrm{~mm}$ from the weld bead centre.

\section{BEAD PROFILES}

The weld pool shape, cooling rates, weld metal composition and grain growth rates are all interrelated to the heat input of the welding process. Hence it is imperative to understand the effect of various levels of heat input and its influence on the bead profile. Specimens were extracted from the mid portion of the welded plates. The cross sectional surface were polished using standard metallographic procedures and etched with aquareagent to get the clear bead profile. The bead profiles were taken using sterozoom microscope with a magnification of $10 \mathrm{X}$. The weld bead profiles and related dimensions are presented in TABLE 5 .

TABLE 5 CROSS SECTIONAL PROFILE OF THE WELD BEADS

\begin{tabular}{|c|c|c|c|c|c|c|c|}
\hline \multirow{2}{*}{$\begin{array}{l}\text { Current } \\
\text { (amps) }\end{array}$} & \multirow{2}{*}{$\begin{array}{l}\text { Constant Current } \\
\text { (CC) }\end{array}$} & \multirow{2}{*}{$\begin{array}{l}\text { Current } \\
\text { (amps) }\end{array}$} & \multirow{2}{*}{$\begin{array}{l}\text { Pulsed Current } \\
\text { (PC) }\end{array}$} & \multicolumn{2}{|c|}{$* \mathrm{P} / \mathrm{T}$} & \multicolumn{2}{|c|}{$\mathrm{W} / \mathrm{P}^{*}$} \\
\hline & & & & $\mathrm{CC}$ & PC & $\mathrm{CC}$ & PC \\
\hline \multirow{3}{*}{80} & $3 \mathrm{~mm}$ & & $3.9 \mathrm{~mm}$ & \multirow{3}{*}{0.35} & \multirow{3}{*}{0.48} & \multirow{3}{*}{4.29} & \multirow{3}{*}{4.11} \\
\hline & $x=3$ & 120 & & & & & \\
\hline & $=0.71$ & & $95 \mathrm{~mm}$ & & & & \\
\hline
\end{tabular}




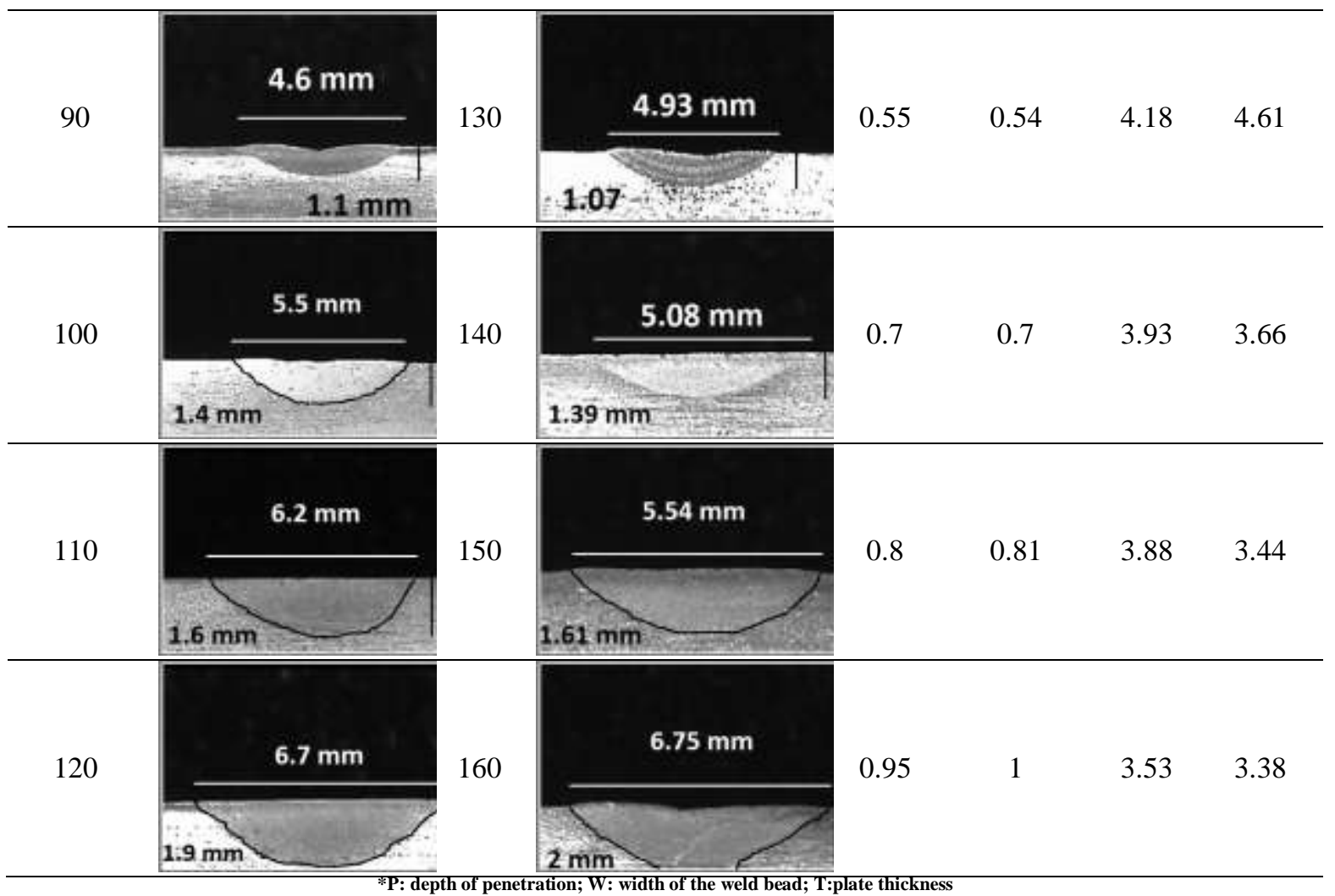

Penetration achieved during welding was compared. From the comparison the joint fabricated at 120 amps in CC had a penetration of $1.9 \mathrm{~mm}$ that was comparable with the joint welded at $160 \mathrm{amps}$ of pulsed current whose penetration was $2.0 \mathrm{~mm}$. The ratio of penetration to plate thickness was 0.95 and 1 for constant current and pulsed current respectively. Both the joints had achieved full penetration. The ratio of width to penetration was 3.53 and 3.38 for constant current and pulsed current respectively. Hence these two joints should exhibit similar characteristics. Various characteristics of the joints such as the tensile properties, microhardness, microstructure and the residual stress are reported.

\subsection{Effect of Pulse Current on Temperature profile}

\section{RESULTS AND DISCUSSION}

The temperatures at $5 \mathrm{~mm}, 15 \mathrm{~mm}$ and $30 \mathrm{~mm}$ from the weld bead centre were measured for 250 seconds. The heating and cooling curves for the various heat input levels are shown in Fig 3 . The values of peak temperature are presented in TABLE 6.

TABLE 6 PEAK TEMPERATURE VALUES AND COOLING RATES

\begin{tabular}{|c|c|c|c|c|c|c|c|c|c|c|}
\hline \multirow[t]{2}{*}{ Exp No } & \multicolumn{2}{|c|}{$\begin{array}{l}\text { Current } \\
\text { (amps) }\end{array}$} & \multicolumn{2}{|c|}{$\begin{array}{l}\text { Heat Input } \\
\text { (Joule/mm) }\end{array}$} & \multicolumn{2}{|c|}{$\begin{array}{c}\text { Peak temp at } 5 \\
\mathrm{~mm} \\
(\mathrm{~K})\end{array}$} & \multicolumn{2}{|c|}{$\begin{array}{l}\text { Cooling Rate } \\
\qquad\left({ }^{\circ} \mathrm{C} / \mathrm{s}\right)\end{array}$} & \multicolumn{2}{|c|}{$\begin{array}{l}\text { Peak temp at } 15 \mathrm{~mm} \\
(\mathrm{~K})\end{array}$} \\
\hline & $\mathrm{CC}$ & $\mathrm{PC}$ & $\mathrm{CC}$ & $\mathrm{PC}$ & $\mathrm{CC}$ & $\mathrm{PC}$ & $\mathrm{CC}$ & $\mathrm{PC}$ & $\mathrm{CC}$ & $\mathrm{PC}$ \\
\hline 1 & 80 & 120 & 152 & 193 & 545 & 558 & 14 & 10.9 & 449 & 453 \\
\hline 2 & 90 & 130 & 189 & 199 & 577 & 561 & 11.8 & 10.8 & 460 & 463 \\
\hline 3 & 100 & 140 & 210 & 223 & 601 & 583 & 9.9 & 10.7 & 490 & 471 \\
\hline 4 & 110 & 150 & 235 & 249 & 617 & 653 & 6 & 9.3 & 502 & 496 \\
\hline 5 & 120 & 160 & 262 & 263 & 632 & 670 & 5.5 & 8.2 & 507 & 509 \\
\hline
\end{tabular}

The total time of welding was 24 seconds. The peak temperature increases as the heat input increases in all the cases. In CC the highest temperature was $632 \mathrm{~K}$ for the higher heat input of $262 \mathrm{~J} / \mathrm{mm}$ and the lowest was $545 \mathrm{~K}$ for $152 \mathrm{~J} / \mathrm{mm}$ at the $5 \mathrm{~mm}$ distance (Fig 3a). In the PC for the $5 \mathrm{~mm}$ distance the highest temperature was $670 \mathrm{~K}$ for the heat input of $263 \mathrm{~J} / \mathrm{mm}$ and lowest peak temperature of $558 \mathrm{~K}$ for a heat input of $193 \mathrm{~J} / \mathrm{mm}(\mathrm{Fig}$ $3 c)$. 


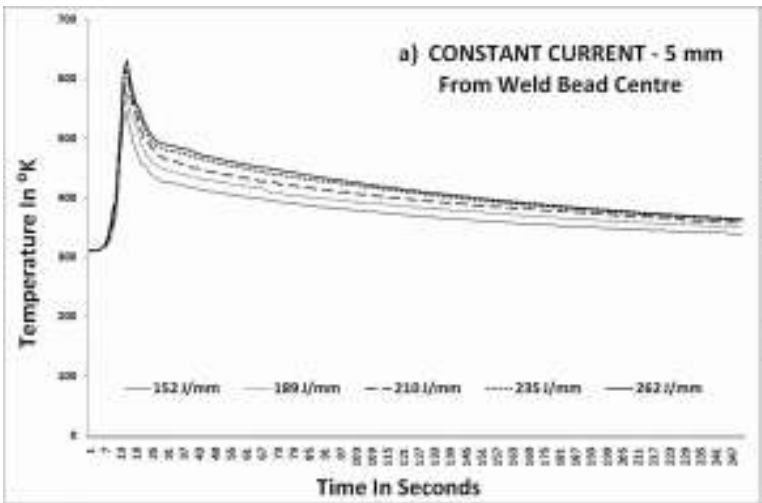

(a) Constant Current $5 \mathrm{~mm}$

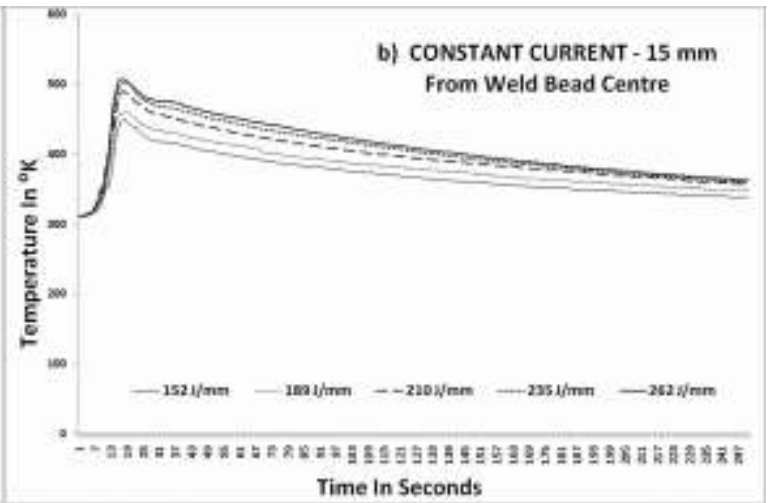

(b) Constant Current $15 \mathrm{~mm}$

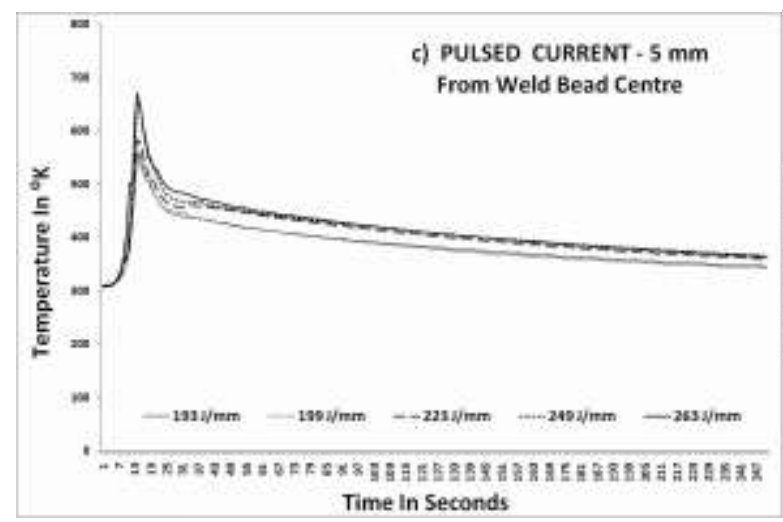

(c) Pulsed Current $5 \mathrm{~mm}$

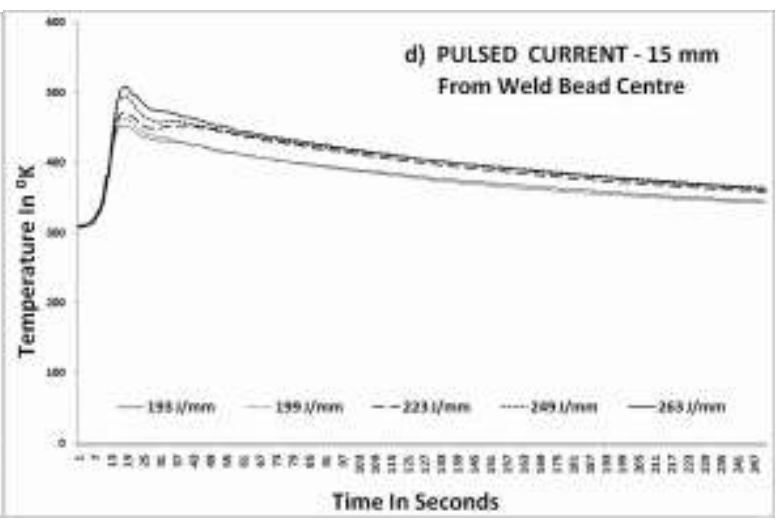

(d) Pulsed Current $15 \mathrm{~mm}$

Figure 3. Heating and cooling curve

From the temperature profiles, closer to the weld bead $(5 \mathrm{~mm})$ it was seen that for PC conditions the heat input of $200 \mathrm{~J} / \mathrm{mm}$ and above the cooling curves tend to cluster together, which was not seen in the cooling curves for the CC. The reason for this can be attributed to the temperature dependent properties of AZ31B magnesium alloy. In addition, when the heating period of 24 seconds is completed the temperature tends to raise and then cool in the case of PC. The reason can be attributed to the thermal conductivity of the base metal, which varies from 515 to $550 \mathrm{~W} / \mathrm{mK}$ in the temperature range of 450 to $500 \mathrm{~K}$, Thereafter the thermal conductivity is linear. During pulsing of the current the temperatures tend to fall below this range, hence to stabilize the temperature of the base metal, this phenomenon is noticed. This raise and drop is not noticed in the CC profiles.

The profiles of temperature at $15 \mathrm{~mm}$ from the centre of the weld bead for PC followed the similar pattern of the $5 \mathrm{~mm}$ profiles and were more profound in these profiles. The reason for this clustering can be attributed to the thermal diffusivity and density of AZ31B Magnesium Alloy, The thermal diffusivity of the base metal remains constant after $500 \mathrm{~K}$, the density of the base material falls steeply after $500 \mathrm{~K}$.

The cooling rate was determined for the temperature drop from $400^{\circ} \mathrm{C}$ to $200^{\circ} \mathrm{C}^{19}$ and presented in Table 6. It shows that for the lower heat input rates the cooling rate is faster and for higher heat inputs the cooling rate is slower, for the lowest heat input the cooling rate for $\mathrm{CC}$ is $14{ }^{\circ} \mathrm{C} / \mathrm{s}$ and for highest heat input it is $5.5^{\circ} \mathrm{C} / \mathrm{s}$. This variation gives equidistant cooling for all heat inputs. For the $\mathrm{PC}$ the cooling rate was $10.9^{\circ} \mathrm{C} / \mathrm{s}$ at the lowest heat input and for the highest heat input level the cooling rate was $8.2^{\circ} \mathrm{C} / \mathrm{s}$. It is seen that the cooling rate for $\mathrm{PC}$ is much faster than that of the $\mathrm{CC}$.

\subsection{Effect of Pulsed Current on Bead Profile}

It is seen from TABLE 5 that for the $\mathrm{CC}$ at the lower heat input levels the penetration was about one fourth of the thickness of the sheet. The profile of the PC were more controlled and the penetration was higher than that of CC. The penetration to width ratio for the PC was higher than that of the $\mathrm{CC}$ and full penetration was achieved for the highest heat input. The effect of the surface tension and buoyancy forces are seen clearly in the lower heat input profile of both constant current and pulsed current but not prominent in all the cases of higher heat input. 


\subsection{Effect of Pulsed Current on Tensile properties}

The tensile properties were compared for the equal penetration welds is presented in TABLE 7 . The cooling rate was 5.5 and $8.2^{\circ} \mathrm{C} / \mathrm{s}$ at $5 \mathrm{~mm}$ from weld bead centre for $\mathrm{CC}$ and $\mathrm{PC}$ respectively, the heat input was $262 \mathrm{~J} / \mathrm{mm}$ and $263 \mathrm{~J} / \mathrm{mm}$. The yield strength for the constant current was $138 \mathrm{MPa}$ but for pulsed current it was higher (155 MPa) and tensile strength followed the same trend as 172 and $194 \mathrm{MPa}$ for the constant current and pulsed current respectively.The failure location for both the cases was at the weld bead. The joint efficiency was $80 \%$ for CC and $90 \%$ for PC. The higher strength is seen in the joint fabricated by the PC due to faster cooling rate and lower peak temperature.

TABLE 7 TENSILE PROPERTIES OF THE WELDED JOINTS

\begin{tabular}{ccccc}
\hline Process & $\begin{array}{c}\text { Yield strength } \\
(\mathrm{MPa})\end{array}$ & $\begin{array}{c}\text { Tensile strength } \\
(\mathrm{MPa})\end{array}$ & $\begin{array}{c}\text { Elongation } \\
(\%)\end{array}$ & Joint Efficiency (\%) \\
\hline Constant Current & 138 & 172 & 4 & 80 \\
\hline Pulsed Current & 155 & 194 & 6 & 90 \\
\hline
\end{tabular}

\subsection{Effect of Pulsed Current on Hardness}

TABLE 8 shows the Vickers hardness values for the two joints at weld zone, $5 \mathrm{~mm}$ and $15 \mathrm{~mm}$ from weld bead centre for CC and PC. The microhardness of the base metal was $69 \mathrm{Hv}$. It was evident that in CC the hardness was the highest at the weld centre and decreased at the $5 \mathrm{~mm}$ point and $15 \mathrm{~mm}$ point. The values of the hardness was less in the CC joints compared to the PC in all the locations. The peak temperature reached for the $\mathrm{CC}$ was $632 \mathrm{~K}$ and for the PC $670 \mathrm{~K}$ at $5 \mathrm{~mm}$ distance from weld centre. The reason for the increase in the hardness of PC can be attributed to the faster cooling rate $\left(8.2^{\circ} \mathrm{C} / \mathrm{s}\right)$ and the higher temperature attained.

TABLE 8 MiCROHARDNESS (Hv) PROFILE

\begin{tabular}{ccccc}
\hline Process & Weld centre & $\begin{array}{c}5 \mathrm{~mm} \text { from } \\
\text { weld centre }\end{array}$ & $\begin{array}{c}15 \mathrm{~mm} \text { from } \\
\text { weld centre }\end{array}$ & $\begin{array}{c}\text { Base } \\
\text { Metal }\end{array}$ \\
\hline Constant Current & 65.5 & 59.9 & 59.35 & 69 \\
\hline Pulsed Current & 71.7 & 66.2 & 64.2 & 69 \\
\hline
\end{tabular}

\subsection{Effect of Pulsed Current on Microstructure}

The strength of the weld metal is characterized by the grain size and the phases present in the microstructure. The phase formation and grain growth are highly influenzed by the thermal cycle of the welding process. The results of the microstructure at the weld centre, Interface region and Heat Affected Zone (HAZ) are presented in Fig 4.

The microstructure of the weld centre reveals coarse grains in the $\mathrm{CC}$ joint while for the PC the grains are fine, the spacing between the grains in the CC is wider but the PC reveals narrower spacing (Fig 4a, Fig 4b). It is also seen that the area of grain boundary is less in the CC compared to that of the PC. The effect of faster cooling rate is seen in the microstructure of the PC specimen with domination of smaller grains. The morphology of the $\mathrm{CC}$ predominates with the elongated coarse grain structure due to the lower cooling rate (Fig 4e, Fig 4f).

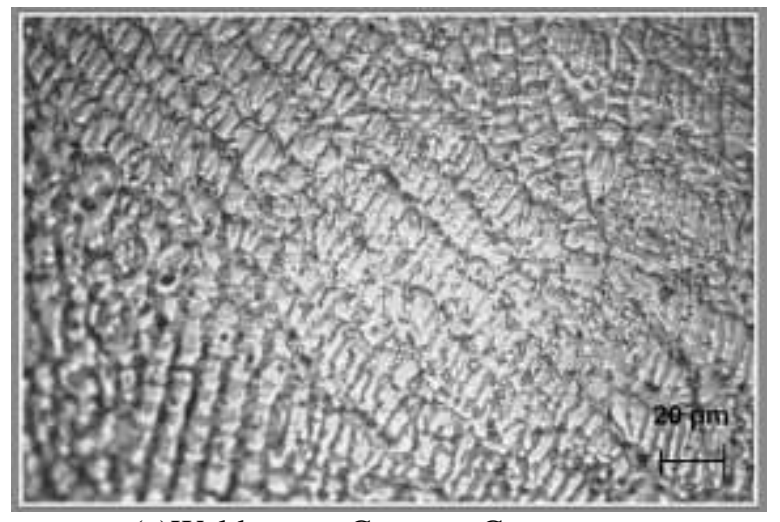

(a)Weld centre Constant Current

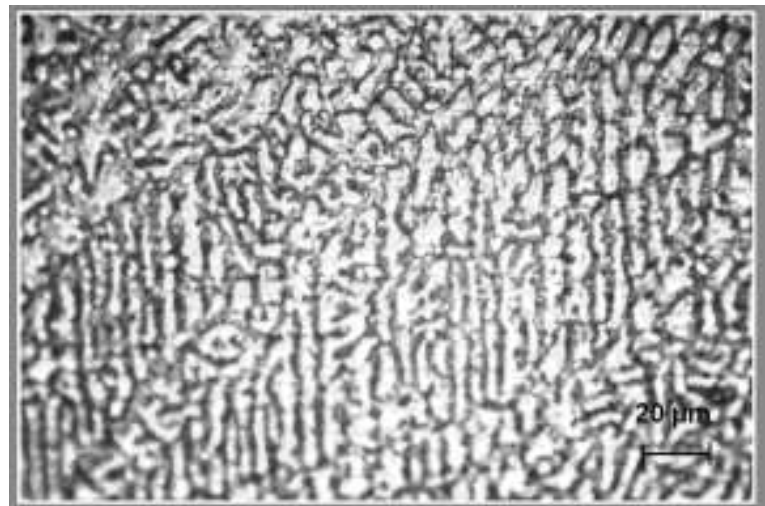

(b)Weld centre Pulsed Current 


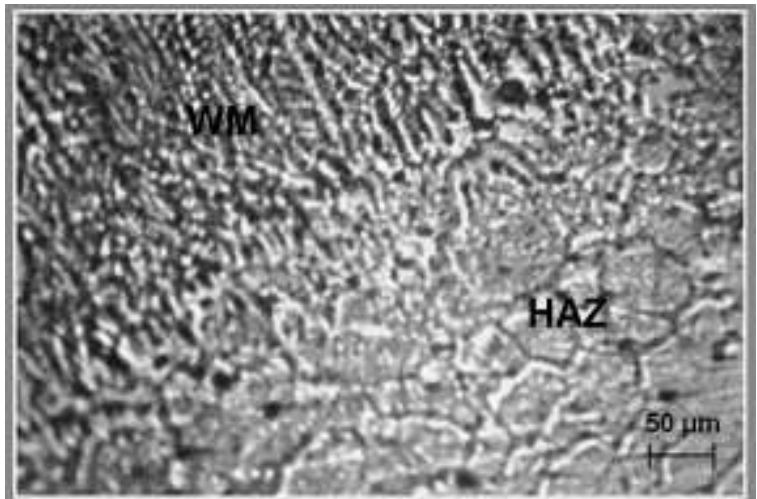

(c)Inter- face (WM-HAZ) Constant Current

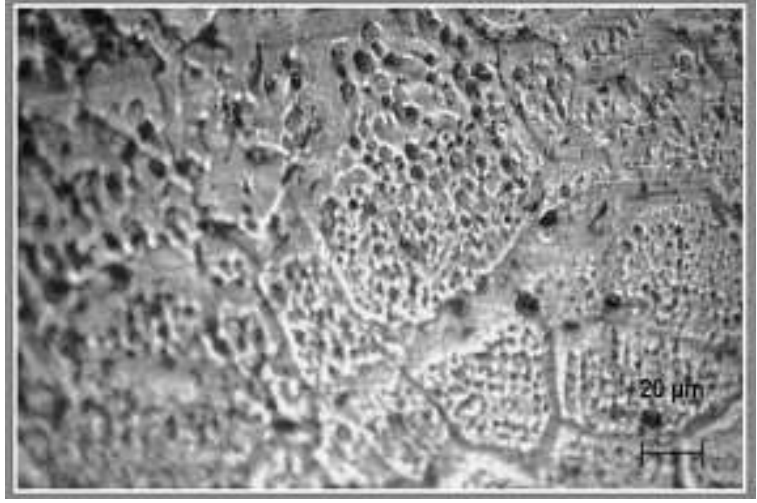

(e)HAZ Constant Current

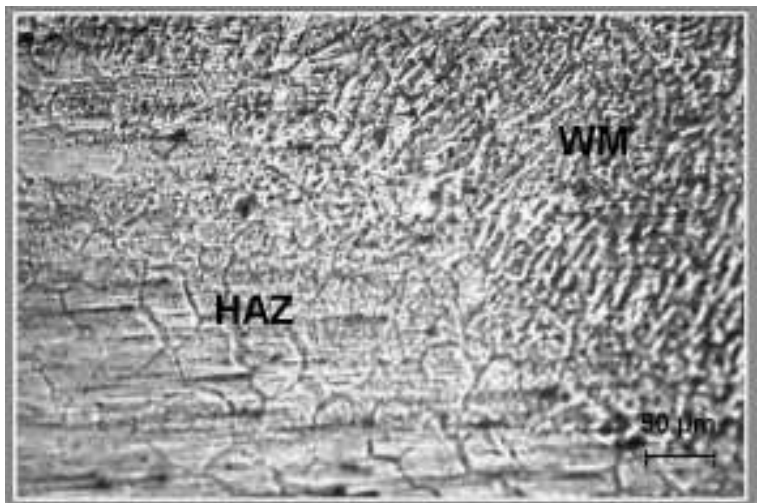

(d)Inter- face (WM-HAZ) Pulsed Current

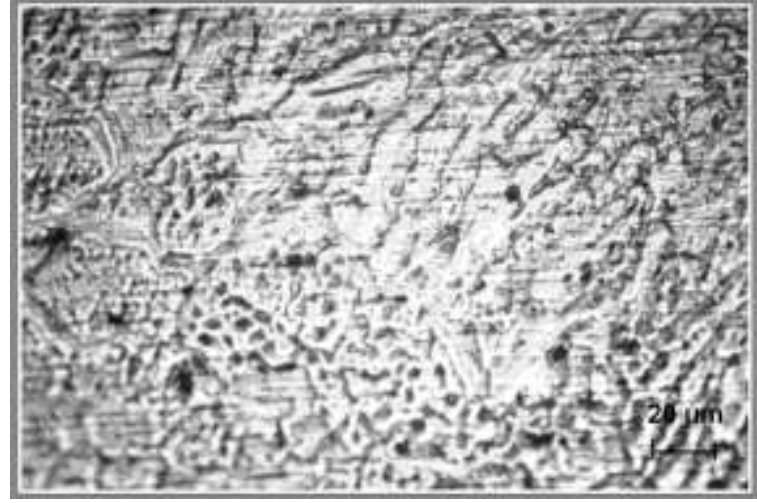

(f)HAZ Pulsed Current

Figure 4. Microstructure

Furthermore, the temperature fluctuations inherent in pulsed welding lead to a continual change in the weld pool size and shape favouring the growth of new grains. It is also to be noted that effective heat input for unit volume of the weld pool would be considerably less in pulse current welds for which reason the average weld pool temperatures are expected to be low [19]. Thus, grain refinement observed in the pulsed current welds is due to effects of pulsing on the weld pool shape, fluid flow and temperatures[20].

\subsection{Effect of Pulsed Current on Residual stress}

Two specimens were taken to determine the residual stress, one from each of the constant current and pulsed current. It is seen from TABLE 9 that both the specimen showed tensile stress at the weld centre, compressive stress at $5 \mathrm{~mm}$ and $15 \mathrm{~mm}$. The base metal had compressive stress. The value of stress at the weld centre for the constant current was 46.2 MPa while that of Pulsed current was 20.1 MPa. This trend was seen in points at $5 \mathrm{~mm}$ and $15 \mathrm{~mm}$ from weld centre. The joints fabricated by the Pulsed current showed less residual stress at weld centre compared to that of constant current. The reason for this characteristic feature can be attributed to the faster cooling rate of $8.2^{\circ} \mathrm{C} / \mathrm{s}$ that was achieved in the pulsed current welds.

TABLE 9 RESIDUAL STRESS (MPA) DISTRIBUTION

\begin{tabular}{ccccc}
\hline Process & Weld centre & $\begin{array}{c}5 \mathrm{~mm} \text { from weld } \\
\text { centre }\end{array}$ & $\begin{array}{c}15 \mathrm{~mm} \text { from } \\
\text { weld centre }\end{array}$ & $\begin{array}{c}\text { Base } \\
\text { Metal }\end{array}$ \\
\hline Constant & 46.2 & -25.2 & -88.5 & -45.2 \\
\hline Pulsed Current & 20.1 & -30.6 & -68.7 & -45.2 \\
\hline
\end{tabular}

\section{CONCLUSION}

From this investigation, it was found that

(i) The pulsed current welding technique recorded higher peak temperatures for comparable heat input levels resulting in faster cooling rates and lower magnitude of residual stresses compared to constant current welding, which is highly preferable for thin sheet welding.

(ii) The gas tungsten arc welded magnesium alloy joint fabricated by pulsed current welding technique exhibited better tensile properties compared to constant current welding technique. 
(iii) The formation of finer grains caused by pulsed current are the main reasons for enhanced tensile and hardness properties of the joints.

\section{Acknowledgements}

The author wish to express his sincere thanks to Dr. V. Balasubramanian of Centre for Materials Joining and Research (CEMAJOR), Department of Manufacturing Engineering, Annamalai University, Annamalai Nagar 608002 for the facilities provided to carry out this investigation and the support rendered during the process of investigation.

\section{REFERENCES}

[1] Senthil Kumar.T, Balasubramanian.V,_Babu.S and Sanavullah.M.Y., Effect of pulsed current GTA welding parameters on the fusion zone microstructure of AA6061 aluminum alloy, Metals and Materials International, Vol.13, No.4, pp. 345-351. 2007.

[2] Prasad Rao K, Reddy G.M. and Gokhale A.A. Grain refinement and improvement of strength and ductility of welds by pulsed current and magnetic arc oscillation techniques, International Welding Conference, New Delhi, pp. 1050-1055. 1999.

[3] Davies CJ and JG Garland Solidification structures and properties of fusion welds, Int. Mater. Review, Vol.20, pp.83-106. 1975.

[4] Kou S and Y.Le Nucleation mechanism and grain refining of weld metal, Welding Journal, Vol 65. pp. 65-70. 1986

[5] Madhusudhan Reddy G, Gokhale A.A and Prasad Rao K Optimization of pulse frequency in pulsed current gas tungsten arc welding of aluminium - lithium alloy sheets, Journal of Material Science \& Technology, Vol. 14, pp. 61-66, 1998

[6] Potluri N.B, Ghosh P.K, Gupta P.C and Reddy Y.S - Studies on weld metal characteristics and their influences on tensile and fatigue properties of pulsed current GMA welded Al-Zn-Mg alloy, Welding Research Supplement, Vol 75, pp 62s-70s. 1996.

[7] Mohandas T and Madhusudhana Reddy G Effect of frequency of pulsing in gas tungsten arc welding on the microstructure and mechanical properties of titanium alloy welds, Jl. of Mater SciLetters, Vol. 15, pp 626-628,1996.

[8] Balasubramanian V, Ravisankar V and Madhusudhan Reddy G, Effect of pulsed current and post weld aging treatment on tensile properties of argon arc welded high strength aluminium alloy, Materials Science and Engineering - A, Vol.459, pp.7-18, 2007.

[9] Balasubramanian M, Jayabalan V and Balasubramanian V, A mathematical model to predict impact toughness of pulsed current gas tungsten arc welded titanium alloy, International Journal of Advanced Manufacturing Technology, Vol.35, No. 9-10, pp.852-858, 2008 .

[10] Lu, M., Kou, S., Power and current distribution in GasTungsten Arcs. Weld. J. Vol 67(2) pp 29s-33s, 1988.

[11] Sadek C, Absi Alfaro, Chawla K S \& John Norrish "Computer Based Data Acquisition for welding research and production" Journal of Materials Processing Technology Vol 53 pp 1-13,1995.

[12] Peter R.N. Childs “Practical Temperature Measurements" Elsevier Publications. 1998

[13] Sunar M, Yilbas B.S, Boran K, "Thermal and stress analysis of a sheet metal in welding" Journal of Materials Processing Technology Vol 172 pp 123-129, 2006.

[14] Paul Scott, "Selecting a welding frequency" article at http://www.thermatool.com/.

[15] Gonsalves C.V, Vilarinho L.O, Scotti A, Guimaraes G. "Estimation of heat source and thermal efficiency in GTAW process by using inverse techniques" Journal of Materials Processing Technology Vol 172, pp 42-51, 2006.

[16] Kim W.H, Na S.J. "Heat and fluid flow in pulsed current GTA weld pool” International Journal of Heat and Mass Transfer Vol 41 pp 3213-3227, 1998.

[17] Fan H.G, Shi Y.W, Na S.J. "Numerical analysis of the arc in pulsed current gas tungsten arc welding using a boundary-fitted coordinate" Journal of Materials Processing Technology Vol 72 pp 437-445. 1997

[18] Lothongkum G, Chaumbai P, Bhandhubanyong P. "TIG pulse welding of 304L austenitic stainless steel in flat, vertical and overhead positions" Journal of Materials Processing Technology, Vol 89 - 90 pp 410 - 414. 1999.

[19] Ravisankar V and Balasubramanian V, Optimising the pulsed TIG welding parameters to refine the fusion zone, Science and Technology of Welding \& Joining, Vol.11, No.6, pp.112-116, 2006.

[20] Norman A.F, Hyde K, Costello F, Thompson S, Birley S and Pragnell P.B Examination of the effect of Sc on 2000 and 7000 series aluminium castings: for improvements in fusion welding, Materials Science and engineering, Vol A 354, pp 188-198. 2003. 